\title{
EFFECT OF ITRACONAZOLE ON LYTIC ANTIBODIES LEVELS IN CHRONIC Chagas disease
}

\author{
VENEGAS J.*, ZULANTAY I.**, APT W.**, SOLARI A.*, DÍAZ E.** \& SÁNCHEZ G.*.
}

\section{Summary :}

We report the chemotherapeutic effect of itraconazole in chronic chagasic patients. The efficacy of treatment was analyzed by xenodiagnosis $(X D)$, conventional serology (CS) and antibody dependent-complement mediated lysis test (CoML). Twenty chronic chagasic persons from endemic areas of Chile were grouped according to the results of xenodiagnosis (XD) performed before therapy. The follow-up of patients was performed at an average time of 42 months after treatment. No significative statistical differences were observed in the result of ELISA and Indirect Immunofluorescence test performed on sera before and after therapy with itraconazole. In the group of patients with positive XD before therapy, sera from six of them displayed lytic activity against Trypanosoma cruzi. The lytic activity of only one of these sera became negative after therapy. In relation to $X D$, five of those patients showed a positive tests at least once during the follow-up period. In the group of ten patients with negative XD before therapy, sera from eight of them displayed lytic activity. At the end of the follow-up period seven of them became negative. Nine of the ten patients maintained their original condition with respect to $X D$. These results suggests that parasitaemia level before therapy condition could be an important parameter to consider in the chemotherapy of chronic Chagas disease.

KEY WORDS : Chagas disease, chemotherapy, itraconazole, xenodiagnosis, conventional serology, lytic antibodies, follow-up.

\section{INTRODUCTION}

7 rypanosoma cruzi infection provokes an acute phase characterized by a great number of circulating parasites, following by a chronic phase with subpatent parasitaemia and scanty cellular parasitism (Wendel et al., 1992). The immune response against T. cruzi, allows the control of exponential parasites growth during the acute phase (Brener, 1980). In the chronic phase the immune response prevents the re-activation of the infection, but several studies show that it is unable to eradicate the parasite in the chagasic patient (Barousse et al., 1980 ; Brener, 1980).

\footnotetext{
* Department of Biochemistry, North Campus, Faculty of Medicine, University of Chile, Santiago-Chile, Independencia 1027 - Fax : 562 (7355580).

** Unit of Parasitology, South Campus, Faculty of Medicine, University of Chile, Santiago-Chile, Gran Avenida 3100 - Fax : 56-2 (5562659). Correspondence : Dr. Gittith Sánchez P., Departament of Biochemistry, North Campus, Faculty of Medicine, University of Chile, Santiago-Chile, Independencia 1027 - Fax : 56-2 (7355580).
}

Résumé : EFFET DE L'ITRACONAZOLE SUR LES TAUX D'ANTICORPS lytiques dans la maladie De Chagas Chronique

L'effet pharmacologique de l'itraconazole chez des patients porteurs de forme chronique de maladie de Chagas est rapporté. L'efficacité du traitement a été analysé par xénodiagnostic (XD), sérologie conventionnelle (CS) et test de lyse utilisant le complément dépendant des anticorps (CoML). Vingt personnes souffrant de Chagas chronique et venant de zones d'endémie au Chili ont été distribuées selon les résultats du xénodiagnostic réalisé avant traitement. Le suivi des patients a été effectué à 42 mois en moyenne après traitement. Aucune différence statisquement significative n'a été observée pour les résultats de I'ELISA et du test d'immunofluorescence indirect réalisés sur les sérums avant et après traitement par l'itraconazole. Dans le sérum de six des patients du groupe XD positif avant traitement, une activité lytique contre Trypanosoma cruzi s'est développée. Un seul d'entre eux s'est négativé après traitement. Dans le groupe des dix patients XD négatifs avant traitement, huit ont développé une activité lytique. Sept se sont négativés avant la fin de la période de suivi. Ces résultats laissent à penser que le niveau de parasitémie avant traitement est un paramètre important à considérer dans la chimiothérapie de la maladie de Chagas chronique.

MOTS CLÉS : maladie de Chagas, chimiothérapie, itraconazole, xénodiagnostic, sérologie, anticorps lytiques, suivi.

The existence of two types af antibodies in chronic chagasic patients have been demonstrated. Lytic antibodies associated with protection, are able to bind to live trypomastigotes and can be detected by antibody dependent complement-mediated lysis test (CoML), (Krettli \& Brener, 1982). On the other hand, conventional antibodies are not protective but are useful for disease diagnosis (Brener, 1980).

The existence of lytic antibodies had been considered as an indicator of active infection and its absence after chemotherapeutic treatment would indicate cure (Brener \& Krettli, 1990). Drugs (Rochagan ${ }^{1}$, Radanil ${ }^{1}$, Lampit ${ }^{2}$ ) utilized in the last decades for antichagasic treatment are potentialy toxic compounds that present diverse secondary manifestations and they are only recommended for acute cases since they play a limited role in the specific treatment of chronic cases (Apt et al., 1986; Galvao et al., 1993).

\footnotetext{
1. Roche Laboratory.

2. Bayer Laboratory
} 
Itraconazole, a synthetic imidazole, was shown to be highly effective against $T$. cruzi both in vivo and in vitro experiments (McCabe et al., 1986). In the present study the efficacy of itraconazole on chronic chagasic patients is evaluated by means of xenodiagnosis, conventional serology and lytic antibodies detection.

\section{MATERIAL AND METHODS}

\section{CONVENTIONAL SEROLOGY TECHNIQUES}

I n order to classify the sera as seropositive or seronegative for Chagas disease, indirect immunofluorescence (IFI) (Camargo, 1979) test and ELISA test (Voller, 1975) were used. It was considered a positive reaction when the titres were equal or higher than $1 / 20$ (IFI) and a discriminative limit of positivity, when the product of the mean arithmetic of negative controls was more than three standard deviations for ELISA.

\section{Xenodiagnosis}

Xenodiagnosis (XD) was applied as described (Schenone et al., 1974). Two boxes (each containing seven nymphs of Triatoma infestans third or fourth instar) were applied before therapy and four boxes after therapy follow up. The faecal content of the bugs was examined 30, 60 and 90 days after their application.

\section{SERA}

Sample from twenty individuals average aged 31 years seropositive for Chagas' disease were taken from distinct areas of Chile. Before therapy, ten of them showed positive xenodiagnosis (Group A) and ten of them negative xenodiagnosis (Group B). All individuals were properly informed about the protocol and accepted to be included voluntary in this study. The present investigation was aproved by the Ethic Committee of Physicians (Santiago, Chile).

\section{DRUG}

Itraconazole (Sporanox ${ }^{3}$ ) in tablets of $100 \mathrm{mg}$ was given as a single daily dose of $6 \mathrm{mg} / \mathrm{kg}$ for 120 days (Apt et al., 1993). The average follow-up period was of 41 and 43 months after treatment for Groups A and $\mathrm{B}$, respectively.

\section{PARASITES}

Trypomastigotes were obtained from a Vero cell culture in RPMI-1640 medium supplemented with $10 \%$ foetal bovine serum at $37^{\circ} \mathrm{C}$ in $5 \% \mathrm{CO}_{2}$. Parasites were collected five days after infection from the supernatant. The strain used (MF) was obtained from a chronic case of Chagas disease in the Metropolitan Region of Santiago, which was a mixture of zymodemes $\mathrm{z} 2 \mathrm{bol}$ and

\footnotetext{
3. Janssen Laboratory, Belgium.
}

$z 1$, but the stock maintained in Vero cell cultures, are classified as zymodeme 1, presumably because z1 clone is selected by this biological system (Wallace $e t$ al., 1995).

\section{ANTIBODY-DEPENDENT COMPLEMENT MEDIATED LYSIS TEST}

It was performed as previously described (Krettli et al., 1982). Briefly, $50 \mu \mathrm{l}$ of trypomastigote forms $\left(5 \times 10^{6}\right.$ parasites $/ \mathrm{ml}$ ) were incubated with $50 \mu \mathrm{l}$ of chagasic serum for $40 \mathrm{~min}$ at $37^{\circ} \mathrm{C}$. The total volume was divided in two aliquots: one half was incubated with an equal volume of inactived complement and the other half with the same volume of active complement for $40 \mathrm{~min}$ at $37^{\circ} \mathrm{C}$. The contents of the tubes were counted in a haemocytometer. The assays were considered positive when the percentage of lysis was higher than $20 \%$. All assays were performed in duplicate and always included positive and negative controls. Fresh human sera were used as source of complement, and were stored in small aliquots at $-82^{\circ} \mathrm{C}$ until use.

\section{RESULTS}

$\bigcirc$ tatistical analysis (Sdenecor \& Cochran, 1967) of our results of conventional serology by IFI and ELISA, demonstrate that no significant differences exist between specific antibodies levels before and after antichagasic treatment (not shown). Table I shows the follow-up period of 11 and 41 months by antibodydependent complement-mediated lysis test of ten chronic chagasic patients, whose XD were positive before therapy with itraconazole (Group A).

In this Group, sera from six of them showed lytic activity before therapy and this condition was maintained until 36 months after treatment. The same analysis performed at 41 months, after the start of therapy, revealed that only one of the six cases present negative lytic activity. In relation to XD test, five patients presented, at least one, positive test during the follow-up period (data not shown).

Table II shows the follow-up period of 11 and 43 months, after the start of therapy performed in the Group of chronic chagasic patients with negative XD before therapy. As can be observed, sera from eight patients displayed lytic activity before treatment. As detected in the first follow-up period, the lytic activity of four of the ten (cases 1,3-5) became negative and this condition was maintained until the last follow-up period of 43 months. Nevertheless, one of them decreased its lytic activity to almost negative level (case 6). In the second follow-up period indeed the case 6 is negative, and two new cases changed from positive to negative lytic activity (cases 7 and 8), maintaining this condition until the last follow-up period. 


\begin{tabular}{|c|c|c|c|c|c|c|c|c|}
\hline$N^{\circ}$ case & $\begin{array}{c}\text { Age } \\
\text { (years) }\end{array}$ & $\begin{array}{c}\text { CoML \% } \\
\text { (before therapy) }\end{array}$ & $\begin{array}{c}\text { Follow-up } 1 \\
\text { (months) }\end{array}$ & CoML \% & $\begin{array}{c}\text { Follow-up } 2 \\
\text { (months) }\end{array}$ & CoML \% & $\begin{array}{c}\text { Follow-up } 3 \\
\text { (months) }\end{array}$ & CoML \% \\
\hline 1 & 45 & 60 & 5 & 89 & 36 & 36 & 40 & 34 \\
\hline 2 & 22 & 68 & 8 & 61 & 32 & 40 & 40 & 35 \\
\hline 3 & 11 & 67 & 8 & 55 & 31 & 44 & 39 & 55 \\
\hline 4 & 47 & 52 & 12 & 47 & 32 & 34 & 40 & 32 \\
\hline 5 & 12 & 88 & 12 & 43 & 32 & 50 & 40 & 2 \\
\hline 6 & 15 & 74 & 13 & 48 & 32 & 32 & 40 & 31 \\
\hline 7 & 42 & 3 & 6 & 5 & 35 & 10 & 43 & 2 \\
\hline 8 & 44 & 5 & 14 & 5 & 35 & 16 & 43 & 3 \\
\hline 9 & 45 & 10 & 12 & 20 & 35 & 5 & 43 & 5 \\
\hline 10 & 33 & 7 & 15 & 7 & 35 & 2 & 43 & 10 \\
\hline Average & 32 & & 11 & & 33 & & 41 & \\
\hline
\end{tabular}

Table I. - Group A. Follow-up by complement mediated lysis test (CoML) of ten chronic chagasic patients with positive xenodiagnosis treated with itraconazole (CoML \% percentages of lysed parasites).

\begin{tabular}{|c|c|c|c|c|c|c|c|c|}
\hline $\mathrm{N}^{\circ}$ case & $\begin{array}{c}\text { Age } \\
\text { (years) }\end{array}$ & $\begin{array}{c}\text { CoML \% } \\
\text { (pretherapy) }\end{array}$ & $\begin{array}{c}\text { Follow-up } 1 \\
\text { (months) }\end{array}$ & CoML \% & $\begin{array}{c}\text { Follow-up } 2 \\
\text { (months) }\end{array}$ & CoML \% & $\begin{array}{c}\text { Follow-up } 3 \\
\text { (months) }\end{array}$ & CoML $\%$ \\
\hline 1 & 45 & 72 & 5 & 14 & 32 & 13 & 40 & 14 \\
\hline 2 & 13 & 91 & 7 & 76 & 32 & 72 & 40 & 83 \\
\hline 3 & 13 & 70 & 7 & 15 & 32 & 3 & 42 & 4 \\
\hline 4 & 30 & 78 & 11 & 4 & 35 & 11 & 40 & 6 \\
\hline 5 & 42 & 51 & 16 & 11 & 35 & 8 & 47 & 7 \\
\hline 6 & 47 & 68 & 16 & 22 & 35 & 20 & 47 & 6 \\
\hline 7 & 49 & 78 & 16 & 64 & 35 & 15 & 52 & 19 \\
\hline 8 & 34 & 72 & 13 & 63 & 32 & 20 & $\mathrm{ND}$ & ND \\
\hline 9 & 7 & 7 & 9 & 2 & 32 & 12 & ND & ND \\
\hline 10 & 6 & 6 & 8 & 6 & 31 & 17 & 39 & 5 \\
\hline Average & 30 & & 11 & & 36 & & 43 & \\
\hline
\end{tabular}

Table II. - Group B. Follow-up by complement mediated lysis test (CoML) of ten chronic chagasic patients with negative xenodiagnosis treated with itraconazole (CoML \% percentages of lysed parasites. ND: not determined)

Only one of these patients with positive lytic serum (case 2), remained positive during all the period of the investigation. Nine of ten patients maintained the original negative $\mathrm{XD}$ during the follow-up period.

\section{DISCUSSION}

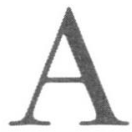

$t$ present there are no effective drugs for the chronic phase of Chagas disease. Therefore, an interesting approach has been the search for new therapeutic agents which are also available for the treatment of others diseases that can be active against T. cruzi (Apt et al., 1994).

The problem in the evaluation on the efficacy of new drugs for anti-chagasic treatment is the absence of a clear criteria of cure after treatment. CoML had been utilized by diverse authors and has been pointed out as useful tool for follow-up studies.

In relation to the results of conventional serology, several hypothesis had been proposed to explain the fact that conventional serology remains positive for long periods in treated individuals that had negativized parasitological tests. One of these hypothesis states that T. cruzi antigens might be sequestrated by dendritic spleen cells. These antigens would maintain an antigenic stimulus during several months after cure. On the other hand, it has been postulated that anti-idiotype raised during the immune response against the parasite, might be maintaining the positive conventional serological tests (Andrade et al., 1988; Gazzinelli et al., 1988).

The results presented in this work show that the CoML test could be a valuable tool to follow-up the treatment efficacy with a new drug in chronic chagasic patients. Nevertheless, it is worth to point out that important differences exist depending on the xenodiagnosis status of infected persons under study. Although XD has a limited sensibility to detect parasitemia in the chronic phase of the disease (Schenone et al., 1974), the present study allowed to demonstrate that the treatment with itraconazole reduced considerably the parasitaemia in five of the ten cases. It is notably that the group of chronic chagasic that can not be evaluated post-therapy by XD since this test is negative before treatment, lytic antibody became an important tool to evaluate treatment efficacy.

Our results show that in the group of patients with positive XD test before treatment only one of the six patients with positive CoML test became negative after 
41 months of the treatment. In contrast, in the negative $\mathrm{XD}$ test group before therapy, the CoML test became negative in seven of eight patients after 41 months of drug treatment. It is interesting to observe that precisely in this second patient group the major percentage of lytic sera before therapy was found. This result reinforces the idea that the low parasitaemia level is being controled by a lytic antibodies response by a still unknown mechanism (Sánchez et al., 1995). This fact strongly suggest that itraconazole might be more effective in those cases of chronic chagasic patients with low parasitaemias since circulating parasites were not detected by XD test. This is in agreement with previous works of our laboratory (Sánchez et al., 1995; Apt et al., 1994). An other interesting point to mention, is that all the cases in which positive lytic sera change to negative lysis, they remain in this condition until the final follow-up period and they did not revert to the previous positive condition. This fact strongly suggest that in those cases the itraconazole treatment was successful (cases 1,3-7) in the elimination of the parasite infection, and also suggest that once the parasite disappear, the lytic immune response also decline. However to confirm this hypothesis should be necessary to follow up thoses patients for a longer period.

\section{ACKNOWLEDGEMENTS}

7 his study was supported by FONDECYT 92092, 1931043 and Fellowship 053-94 from Postgraduate and Post-title Department of the University of Chile.

\section{REFERENCES}

Andrade S.G., Freitas L.A., Peyrol S., Pimentel A.R. \& Sadigursky M. Trypanosoma cruzi antigens detected immunoelectron microscopy in the spleen of mice serologically positive but parasitologically cured by chemotherapy. Revista da Sociedad Brasileira de Medicina Tropical, 1988, 21, 41-42.

Apt W., Arribada A., Arab F., Ugarte F., Luksic I. \& Sole C. Clinical trial of benznidazole and an immnunopotentiator against Chagas disease in Chile. Transactions of the Royal Society Tropical Medicine and Hygiene, 1986, 80, 1010.

Apt W., Aguilera X., Arribada A., Pérez C., Miranda C., Zulantay I., Apt P., Cortés P. \& Rodríguez J. Tratamiento de la enfermedad de Chagas humana crónica con itraconazol y alopurinol. Informe preliminar. Revista Médica de Chile, 1994, 122, 420-427.

Barousse A., Costa J., Eposto U., laplume H. \& Segura E. Enfermedad de Chagas e inmunosupresión. Medicina (Buenos Aires), 1980, 40, Suppl 1, 17-26.

Brener Z. Immunity to Trypanosoma cruzi. In Advances in Parasitology (Lumsden W.H.R., Muller \& Baber, J. eds.). Academic Press, 1980, pp 247-292.

Brener Z. \& Andrade Z. Trypanosoma cruzi e Doença de Chagas. (Guanabara Koogan eds.), 1979, R.J. Brazil. 463 p.
Brener Z. \& KretTli A. Immunology of Chagas disease, in Modern Parasite Biology Cellular. Immunological and Molecular aspects (David J. Wiler, Freeman W.H. \& Company N.Y. eds.), 1990, p 247-261.

CAMARGO E. Fluorescence antibody test for the serodiagnosis of American trypanosomiasis. Technical modification employing preserved culture forms of Trypanosoma cruzi in slide test. Revista do Instituto de Medicina Tropical de Sao Paulo, 1979, 8, 227-234.

Galvao L.M.C., Nunes R.M., Cançado J.R., Brener Z. \& Krettli A.U. Lytic antibody titre as a means of assessing cure after treatment of Chagas disease: a 10 year follow-up study. Transactions of the Royal Society of Tropical Medicine and Hygiene, 1993, 87, 220-223.

Gazzinelli R.T., Morato M.J.F., Nunes R.M.B., Cançado J.R., Brener Z. \& Gazzinelli G. Idiotype stimulation of T lymphocytes from Trypanosoma cruzi infected patients. The Journal of Immunology, 1988a, 140, 3167-3172.

Gazzineldi T., Galvo L.M.C., Krautz G., Lima A.P., CanÇADO J.R., Scharfstein, \& Krettli, A.U. Use of Trypanosoma cruzi purified glycoprotein (GP7/51) or trypomastigoteshed antigens to assess cure for human Chagas disease. American Journal Tropical Medicine and Hygiene, 1993, 49, 625-635.

Krettli A.U., Cançado R. \& Brener Z. Effect of specific chemotherapy on the levels of lytic antibodies in Chagas disease. Transactions of the Royal Society of Tropical Medicine and Hygiene, 1972, 76, 2009-2012.

Krettli A.U. \& BREner Z. Resistance against Trypanosoma cruzi associated to anti-living trypomastigotes. The Journal of Immunology, 1982, 128, 2009-2012.

McCabe R., Remington J. \& Araujo F. In in vitro and in vivo effects of itraconazole against Trypanosoma cruzi. American Journal of Tropical Medicine and Hygiene, 1986, 35, 280-284

Sánchez G., Zulantay I., Venegas J., Solari A., Galvez R., Peña P., Rodríguez J. \& APT W. Treatment with allopurinol and itraconazole changes lytic activity activity in patients with chronic, low grade Trypanosoma cruzi infection. Transactions of the Royal Society of Tropical Medicine and Hygiene, 1995, 89, 438-439.

Schenone H., Alfaro E. \& Rojas A. Bases y rendimiento del xenodiagnóstico en la infección chagásica humana. Boletín Chileno de Parasitología, 1974, 29, 24-26.

Sdenecor G., Cocran W. Statistical Methods. Sixth Edition. Yowa State, University. 1967.

VOlLer A. Microplate enzyme linked immunosorbent assay for Chagas disease. Lancet, 1975, 1, 428.

Wallace A., Sanchez G., Venegas J. \& Solari A. Lack of crossreactivity of lytic antibodies with bloodstream forms of Trypanosoma cruzi zymodeme generated in a mouse experimental model. Experimental Parasitology, 1995, 80, 176-185.

Wendel S., Ener Z., Camargo A. \& Rassi, A. Chagas disease (American trypanosomiasis): Its impact on transfusion and clinical medicine, 1992.1ª Ed. ISBT, Sao Paulo, Brazil.

Reçu le 18 décembre 1996 Accepté le 25 avril 1997 